Original article

https://doi.org/10.26565/2311-0872-2019-30-01

УДК 550. 388

\title{
IONOSPHERIC PROCESSES OBSERVED WITH THE PASSIVE OBLIQUE- INCIDENCE HF DOPPLER RADAR
}

\author{
Qiang Guo $^{1}$, Yu Zheng ${ }^{2}$, L. F. Chernogor ${ }^{3}$, K. P. Garmash ${ }^{3}$, V. T. Rozumenko ${ }^{3}$ \\ ${ }^{1}$ Harbin Engineering University, 145 Nantong Street, Nangang District, Harbin, 150001, China \\ E-mail::guoqiang@hrbeu.edu.cn \\ ${ }^{2}$ Qingdao University, 308 Ningxia Road, Qingdao, 266071, China \\ E-mail: zhengyu@qdu.edu.cn \\ ${ }^{3}$ V. N. Karazin Kharkiv National University, 4, Svobody Square, Kharkiv, 61022, Ukraine \\ E-mail: Leonid.F.Chernogor@gmail.com
}

Received 10 March 2019

Urgency. The urgency is caused by the need to continuously monitor with radio instrumentation dynamic processes acting in the ionosphere, which arise due to variations in space weather, the impact of high-energy sources of natural and anthropogenic origin. To meet this challenge, V. N. Karazin National University and Harbin Engineering University specialists has developed a coherent multi-frequency multi-path radio system for obliquely probing the ionosphere.

Purpose of Work. The paper illustrates the instrument capability for the study of dynamic processes arising in the ionosphere during a solar terminator, a moderate earthquake, a strong ionospheric storm, and in the cource of a partial solar eclipse.

Techniques and Methodology. The system design is base on the software-defined radio (SDR) technology. The system is capable of receiving radio waves in the $10 \mathrm{kHz}-30 \mathrm{MHz}$ band. The versatile computer software permits us to adjust the system for solving various problems. The number of the radio propagation paths and their orientation depends on the problem being solved. The premise upon which this radio system operation is based is measurements of the Doppler shift of the frequency. The autoregressive algorithm provides a $0.02 \mathrm{~Hz}$ root-mean-square Doppler line error and 7.5-s time resolution. Having the Doppler spectrum time dependencies for various radio paths archived, time series corresponding to various radio-wave modes undergo further processing.

Results. As an example of successful instrument performance, dynamic processes operating in the course of a dusk terminator, the moderate (magnitude 5.9) earthquake on July 7, 2018, the strong ionospheric storm on August 26, 2018, and the partial (0.74 magnitude) solar eclipse over China on August 11, 2018 have been investigated. The ionospheric response to the impact of energy sources of various nature has been detected and investigated; it was accompanied by an increase in the number of rays, Doppler spectrum broadening, aperiodic and quasi-periodic variations in the Doppler shift of the frequency, generation of alternating sign variations in the electron density and wave disturbances having atmospheric gravity wave and infrasound parameters.

Conclusions. The radio system located at the Harbin Engineering University campus successfully performs continuous radio monitoring of dynamic processes caused by various energy source in the ionosphere.

KEYWORDS: HF Doppler radar, multipath observations, multi-frequency system, oblique-incidence ionospheric sounding, Doppler shift, Doppler spectra, solar terminator, earthquake, ionospheric storm, solar eclipse, aperiodic disturbances, wave-like disturbances, increase in a ray number

\section{ІОНОСФЕРНІ ПРОЦЕСИ, ЯКІ СПОСТЕРІГАЛИСЬ ПАСИВНИМ ВЧ РАДАРОМ ПРИ ПОХИЛОМУ ЗОНДУВАННІ}

Qiang Guo ${ }^{1}$, Yu Zheng², Л. Ф. Чорногор ${ }^{3}$, К. П. Гармаш ${ }^{3}$, В. Т. Розуменко ${ }^{3}$

${ }^{1}$ Харбінський інженерний університет, 145 Nantong Street, Nangang District, Harbin, 150001, Китай

${ }^{2}$ Qingdao University, 308 Ningxia Road, Qingdao, 266071, Kumaŭ

${ }^{3}$ Харківський національний університет імені В. Н. Каразіна, 61022, м. Харків, м. Свободи, 4

\begin{abstract}
Актуальність. Актуальність обумовлена необхідністю безперервного радіофізичного моніторингу динамічних процесів в іоносфері, викликаних варіаціями космічної погоди, впливом високоенергійних джерел природного й антропогенного походження. Для цього фахівцями 3 Харківського національного університету імені В. Н. Каразіна та Харбінського інженерного університету розроблено когерентний багаточастотний багатотрасовий радіотехнічний комплекс похилого зондування іоносфери.

Метою роботи $є$ ілюстрація працездатності комплексу на прикладі вивчення динамічних процесів в іоносфері при русі сонячного термінатора, протягом помірного землетрусу, сильної іоносферної бурі та в період часткового сонячного затемнення.
\end{abstract}


Методи і методологія. При розробці комплексу використовувалася технологія програмного радіо (SDR). Комплекс здатний приймати радіосигнали в діапазоні частот 10 кГц-30 МГц. Розроблено оригінальне програмне забезпечення, яке залежить від кола розв'язуваних задач. Кількість радіотрас та їх орієнтація залежать від специфіки розв'язуваних задач. У основі функціонування комплексу лежать вимірювання доплерівського зсуву частоти. За допомогою авторегресійного алгоритму забезпечується роздільна здатність за частотою 0.02 Гц та за часом 7.5 с. Після отримання часових залежностей доплерівських спектрів для різних трас виконується подальша обробка часових рядів, що відповідають різним модам радіохвилі.

Результати: Успішне функціонування комплексу продемонстровано на прикладі дослідження динамічних процесів в іоносфері при русі сонячного термінатора, протягом помірного (М $\approx 5.9)$ землетрусу 7 липня 2018 р., сильної іоносферної бурі 26 серпня 2018 р. та в період часткового (фаза близько 0.74) сонячного затемнення над Китаєм 11 серпня 2018 р. Виявлено та досліджено реакцію іоносфери на вплив джерел енерговиділення різної природи, яка супроводжувалася посиленням багатопроменевості, уширенням доплерівських спектрів, аперіодичними та квазіперіодичними варіаціями доплерівського зсуву частоти, генерацією знакозмінних варіацій концентрації електронів і хвилевих збурень 3 параметрами атмосферних гравітаційних хвиль та інфразвуку.

Висновок: Розміщений на території Харбінського інженерного університету комплекс успішно здійснює безперервний радіофізичний моніторинг динамічних процесів в іоносфері, викликаних різними джерелами енерговиділення.

КЛЮЧОВІ СЛОВА: ВЧ доплерівський радар, багатотраєкторні спостереження, багаточастотна система, похиле зондування іоносфери, доплерівський зсув, доплерівські спектри, сонячний термінатор, землетрус, іоносферна буря, сонячне затемнення, аперіодичні збурення, хвилеподібні збурення, багатопроменевість

\section{ИОНОСФЕРНЫЕ ПРОЦЕССЫ, КОТОРЫЕ НАБЛЮДАЛИСЬ ПАССИВНЫМ ВЧ РАДАРОМ ПРИ НАКЛОННОМ ЗОНДИРОВАНИИ} Qiang Guo ${ }^{1}$, Yu Zheng ${ }^{2}$, Л. Ф. Черногор ${ }^{3}$, К. П. Гармаш ${ }^{3}$, В. Т. Розуменко ${ }^{3}$

${ }^{1}$ Харбинский инженерный университет, 145 Nantong Street, Nangang District, Harbin, 150001, Kuтай ${ }^{2}$ Qingdao University, 308 Ningxia Road, Qingdao, 266071, Kumaŭ

${ }^{3}$ Харьковский нацииональний университет имени В. Н. Каразина, 61022, г. Харьков, пл. Свободы, 4

Актуальность. Актуальность обусловлена необходимостью непрерывного радиофизического мониторинга динамических процессов в ионосфере, вызванных вариациями космической погоды, воздействием высокоэнергичных источников природного и антропогенного происхождения. Для этого специалистами из Харьковского национального университета имени В. Н. Каразина и Харбинского инженерного университета разработан когерентный многочастотный многотрассовый радиотехнический комплекс наклонного зондирования ионосферы.

Целью работы является иллюстрация работоспособности комплекса на примере изучения динамических процессов в ионосфере при движении солнечного терминатора, в течение умеренного землетрясения, сильной ионосферной бури и в период частного солнечного затмения.

Методы и методология. При разработке комплекса использовалась технология программного радио (SDR). Комплекс способен принимать радиосигналы в диапазоне частот 10 кГц - 30 МГц. Разработано оригинальное программное обеспечение, зависящее от круга решаемых задач. Количество радиотрасс и их ориентация зависят от специфики решаемых задач. В основе функционирования комплекса лежат измерения доплеровского смещения частоты. При помощи авторегрессионного алгоритма обеспечивается разрешающая способность по частоте 0.02 Гц и по времени 7.5 с. После получения временны́х зависимостей доплеровских спектров для различных трасс производится дальнейшая обработка временны́х рядов, соответствующих различным модам радиоволны.

Результаты: Успешное функционирование комплекса продемонстрировано на примере исследования динамических процессов в ионосфере при движении солнечного терминатора, в течение умеренного $(\mathrm{M} \approx 5.9)$ землетрясения 7 июля 2018 г., сильной ионосферной бури 26 августа 2018 г. и в период частного (фаза около 0.74) солнечного затмения над Китаем 11 августа 2018 г. Обнаружена и исследована реакция ионосферы на воздействие источников энерговыделения различной природы, которая сопровождалось усилением многолучевости, уширением доплеровских спектров, апериодическими и квазипериодическими вариациями доплеровского смещения частоты, генерацией знакопеременных вариаций концентрации электронов и волновых возмущений с параметрами атмосферных гравитационных волн и инфразвука.

Выводы: Размещенный на территории Харбинского инженерного университета комплекс успешно осуществляет непрерывный радиофизический мониторинг динамических процессов в ионосфере, вызванных различными источникам энерговыделения.

КЛЮЧЕВЫЕ СЛОВА: ВЧ доплеровский радар, многотрассовое зондирование, многочастотный радиотехнический комплекс, наклонное зондирование ионосферы, доплеровское смещение, доплеровские спектры, солнечный терминатор, землетрясение, ионосферная буря, солнечное затмение, апериодические возмущения, волнобразные возмущения, многолучёвость 


\section{INTRODUCTION}

The capabilities of probing the ionosphere with radio sounders at oblique incidence for solving the problems of radio wave propagation, ionospheric physics, and dynamic processes acting in the ionosphere are greater than the capabilities of digisondes operating at vertical incidence [1, 4, $7-22]$. In the former case, intercepted signals from non-dedicated, as well as dedicated transmitters, high-frequency (HF) transmitters, e.g., the Super Dual Auroral Radar Network (SuperDARN) of HF radars (see, e.g., [23]), may be used. Observations at oblique incidence allow the radio systems to study a wide area and provide a global picture of evolving and changing dynamic structures. The receivers and transmitters operating at different frequencies and located at the same sites are used for studying the height variations in these processes. The employment of long-distance radio broadcasting in the high frequency band makes the continuous monitoring of dynamic processes operating at ionospheric heights inexpensive. The advantage of such observations is that the interference signals, which would be generated by the dedicated transmitters, are absent. Taking into account the above-mentioned reasoning, the multi-path multi-frequency radio system has been developed for probing the ionosphere at oblique incidence. Dynamic processes acting in the ionosphere have already been observed at oblique incidence by many researchers for a long time [17 - 22].

\section{INSTRUMENTATION AND TECHNIQUES}

The researchers at the Harbin Engineering University (PRC) and V. N. Karazin Kharkiv National University have designed and produced the HF multi-path multi-frequency passive radar capable of monitoring dynamic processes operating in the ionosphere. The radar was placed in operation in May 2018. The experience of creating radio systems, which was gained in developing the radio instruments at the V. N. Karazin Kharkiv National University Radio Physics Observatory [18 - 20], was utilized to design the passive radar.

The purpose of this paper is to present a brief description of the ionospheric observations made at oblique incidence on several frequencies over multiple radio paths from the Harbin Engineering University $\left(45.78^{\circ} \mathrm{N}\right.$, $126.68^{\circ} \mathrm{E}$ ) where the passive Doppler radar is located [24-32]. The parameters of the midlatitude ionosphere in the $\sim 100$ - to $300-400-\mathrm{km}$ altitude are measured by using the coherent passive radar at multiple frequencies. The basic premise upon which the development of the passive radar is based is the software-defined radio (SDR) technology. The radar is capable of operating within the frequency range of $10 \mathrm{kHz}$ to $30 \mathrm{MHz}$, and it includes the active antenna, the LFRX/LRTX boards, the wideband SDR receiver USRP N210, and a PC. The signal processing is performed with the computer program developed to provide very versatile system performance. The antenna intercepts signals in the $10-\mathrm{kHz}$ to $30-\mathrm{MHz}$ range and supplies them to the receiver, which selects the desired HF transmissions from communications and dedicated radio transmitters. The specifics of the study is the usage of a number of orientations of the propagation paths. In this study, twelve propagation paths of various orientations have been used. The basic premise upon which the system operation is based is the measurement of the Doppler shift, $f_{D}$, of the frequency, which is measurable within the $\sim 0.01-\mathrm{Hz}$ to $\sim 1-\mathrm{Hz}$ range. The passive radar makes the measurements continuously. The rate at which the radar takes 16-bit samples is equal to $12,500,000$ samples/s. The radio frequency of every radio transmission is down-converted to zero, the radar sampling is decimated by a factor of 500 twice resulting in a rate of 50 samples per second and a $25-\mathrm{Hz}$ bandpass filtering. The data acquired continuously are stored in the database. In every 20.5-s interval, two thousand forty eight lines in Doppler spectra are calculated in $0.0122-\mathrm{Hz}$ step, which provides the 0.05-Hz Doppler resolution. The analysis of the spectra utilizes the Marple autoregressive algorithm [33] that provides a $0.02-\mathrm{Hz}$ root-mean-square error in the Doppler line shift. The spectra are calculated at a rate of $0.13 \mathrm{~s}^{-1}$, ten-spectrum averaged, archived in the database, and fed on the system console at a rate of $0.13 \mathrm{~s}^{-1}$. In real time, the computer program calculates only signal parameters, that are enough to solve some problems of interest. The Doppler spectra archived in the database can be retrieved in the future and used to plot sequences of graphs for analyzing the conditions on the required radio propagation paths.

Another way of analyzing the data is to determine the Doppler shifts, $f_{D a}$, of the amplitude peaks in the spectra, to extract them from all Doppler spectra, and to form separate sequences for every propagation mode or polarization state. Subsequently, the time series of the Doppler shifts are subjected to various types of analysis (e.g., wavelet analysis, fractal analysis, etc.).

In the current HF Doppler investigations, the Doppler spectra are retrieved from the database and used to analyze the response of the ionosphere to the release of energy from energy sources of natural origin, e.g., the solar terminator, the partial solar eclipse over the PRC, ionospheric storms, and other causes of variability in the ionosphere. Different ionospheric disturbances are produced by different transport processes, which have their own signatures in series of the Doppler spectra. The arrival of a consecutive disturbance is manifested by change in characteristic variations in a series of the Doppler spectra. The change is identified by examination of the Doppler spectrum sequences. 
1. Solar Terminator.

\section{OBSERVATIONS}

Fig. 1 shows the plots of the raw Doppler spectra, with universal time along the abscissa and the Doppler shift along the ordinate. The sequence of panels is read from top to bottom and left to right for
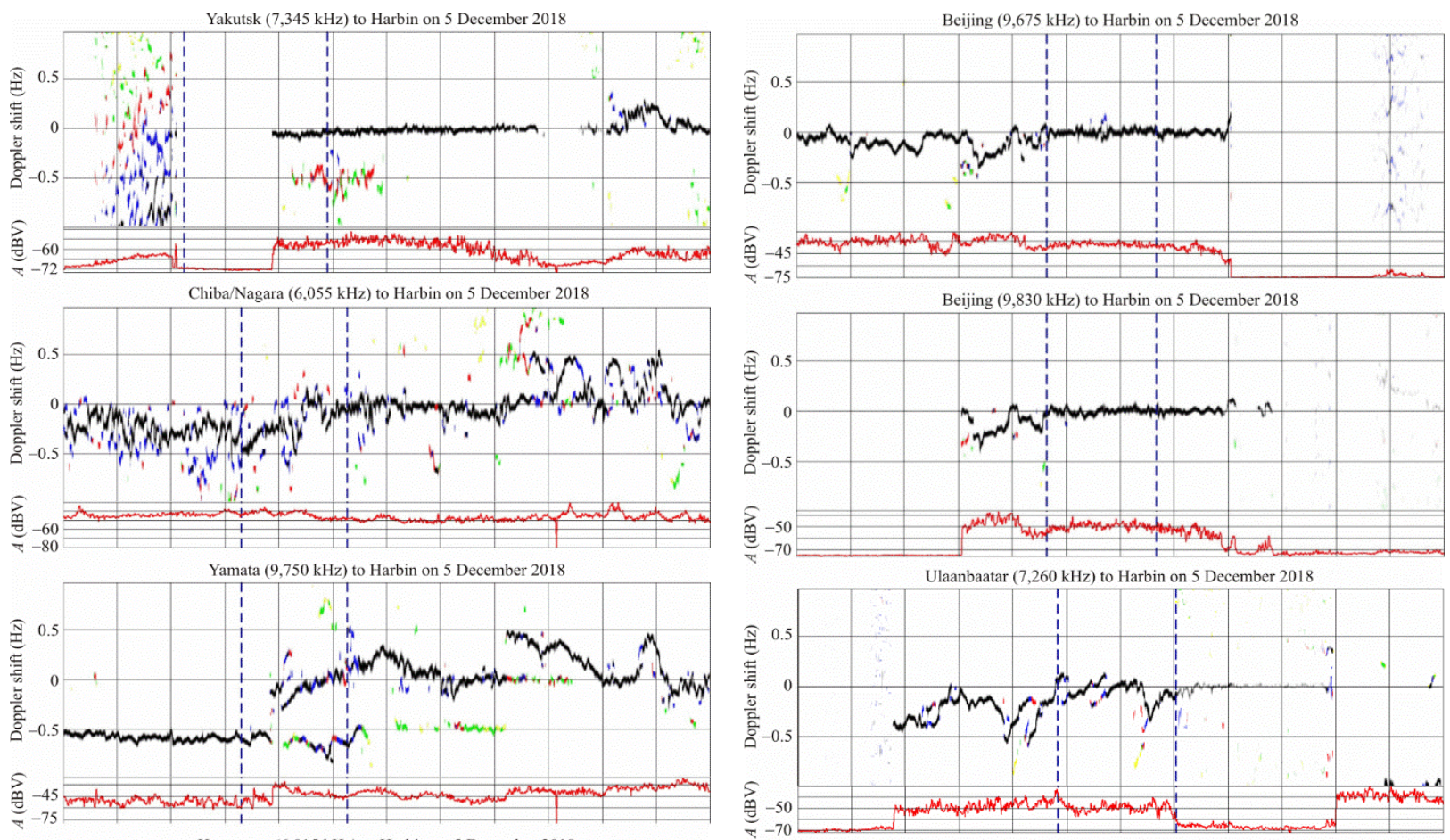

Hwaseong $(6,015 \mathrm{kHz})$ to Harbin on 5 December 2018

Shijiazhuang $(9,500 \mathrm{kHz})$ to Harbin on 5 December 2018
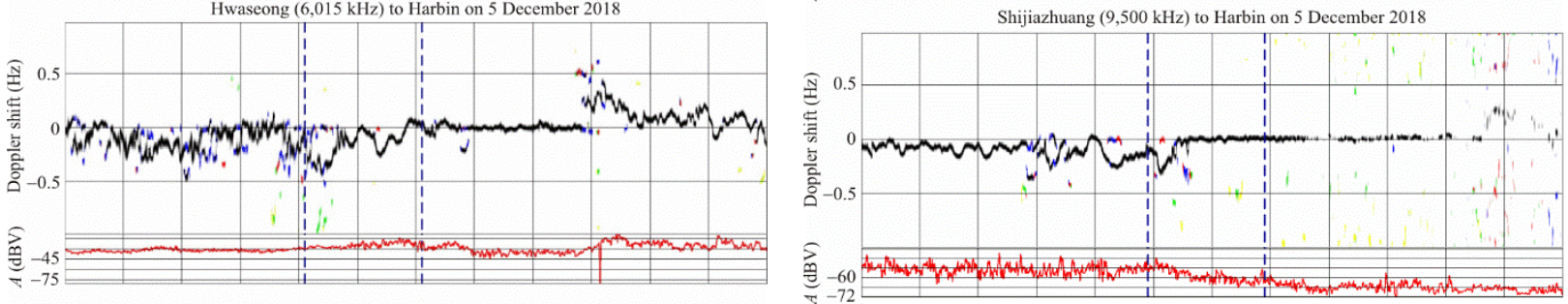

Goyang $(6,600 \mathrm{kHz})$ to Harbin on 5 December 2018
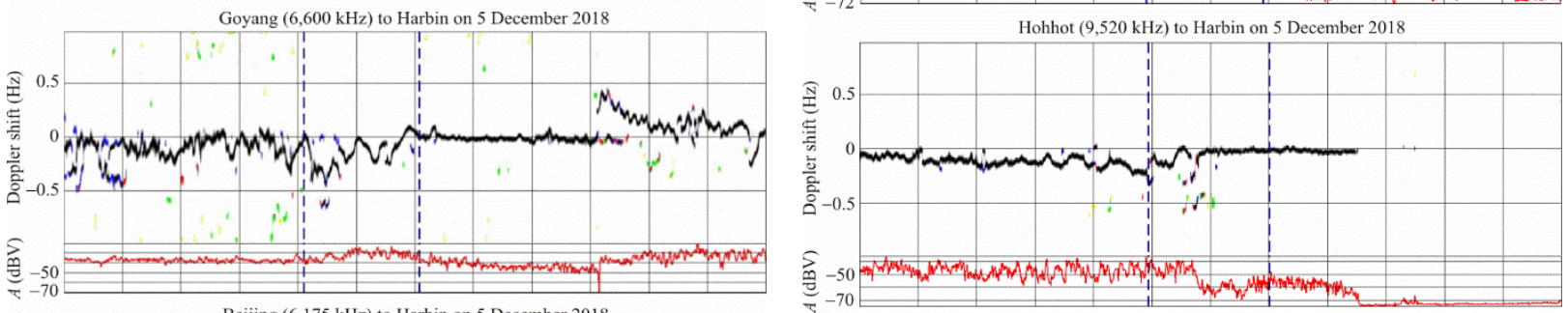

Beijing $(6,175 \mathrm{kHz})$ to Harbin on 5 December 2018
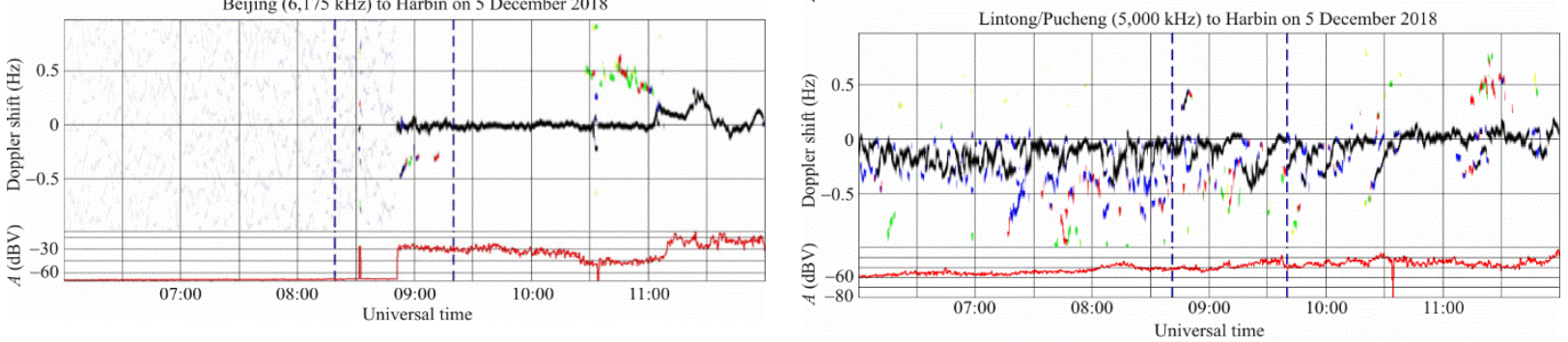

Fig. 1. Universal time variations in Doppler spectra and amplitude, $A$, of the signal in relative units observed on 5 December 2018. Dashed lines mark the times of sunset at the ground and at an altitude of $100 \mathrm{~km}$. One-hour interval of Doppler shift graph consists of 117,600 points. Amplitude, A, of the signal in decibels, dBV, vs. $1 \mathrm{~V}$ at the output of the receiver is presented in each panel.

Chiba/Nagara to Harbin, Yamata to Harbin, Hwaseong to Harbin, Goyang to Harbin, Beijing to Harbin, Shijiazhuang to Harbin, Hailar/ Nanmen to Harbin, Hohhot to Harbin radio propagation paths on 5 December 2018, respectively. Under the Doppler spectrum graph in each panel, also shown is the amplitude, A, of the signal at the output of the receiver in decibels, $\mathrm{dBV}$, relative to $1 \mathrm{~V}$. 
Fig. 1 illustrates the effect that the dusk terminator has on the time series of the Doppler spectra and the signal amplitude. The sunset at the ground and at 100-km altitude are designated by the vertical dashed lines. The important feature to note is that the effects of the dusk terminator started appearing about $1-1.5 \mathrm{~h}$ before the sunset at the ground. The dusk terminator effects are observed both during and after this process ceases. The effects of the solar terminator in the ionosphere are manifested by a variety of processes. First, in the HF Doppler shift observations, they appear as diffusive spectra. Usually, this effect is due to the scattering of the probing signals by electron-density irregularities in the ionosphere. The Doppler spectrum broadening reaches $0.5-1$ $\mathrm{Hz}$. Second, the movement of the terminator causes the generation of the atmospheric gravity waves, in the $15-$ 30-min period range, which are manifested by Doppler shift variations with an about $0.05-0.15-\mathrm{Hz}$ amplitude. Third, often, a second or even a few rays appear. A positive $0.3-0.5-\mathrm{Hz}$ Doppler spectrum shift of the second mode can be seen over the Beijing to Harbin, Yamata to Harbin, Hwaseong to Harbin, Chiba/Nagara to Harbin, Goyang to Harbin radio propagation paths. Such magnitudes of the Doppler shift could be caused by electron density variations of the order of $\sim 1-10 \%$ in the $E$ and $F$ regions, respectively. Over a 30-min interval (10:30 UT to 11:00 UT), the Doppler shift shows a slow decrease to zero, and the second and the main mode combine at the end of this period. Next, the Doppler shift exhibits small quasi-periodic oscillations over the same radio propagation paths.

\section{Moderate Earthquake}

The submarine earthquake occurred of the coast of Japan at 11:23:50 UT on 7 July 2018, with the epicenter coordinates $35.107^{\circ} \mathrm{N}, 140.42^{\circ} \mathrm{E}$ and with the hypocenter at a depth of $40 \mathrm{~km}$. The earthquake magnitude on the Richter scale was 5.9. The distance between the earthquake epicenter and the City of Harbin was equal to 1,650 $\mathrm{km}$.

Table 1 summarizes data on space weather state, which are needed for interpreting processes acting in the ionosphere. Presented in Table 1 are the following (from left to right): the sunspot number $W$, the 10.7-cm solar radio flux $F 10.7$, the 3 -hr planetary $K p$ index, the equatorial hourly $D s t$ index, the interplanetary magnetic field $B_{z}$ component, and the daily activity index $A p$. The space weather state on 7 July 2018 was conducive for observing the effects of the earthquake in the ionosphere. During two days before the earthquake, only two following disturbances occurred. First, a minor-to-moderate geomagnetic storming occurred on July 52018 when the $K p$ and $D s t$ indices reached maximum values. During extremely low solar activity, storms such as this could have quite significant ionospheric effects. Second, on 6 July 2018, a small burst in solar radiation occurred. The fluxes of charge particles measurements were at a level the background noise. The $K_{p}$ index did not attain 2, except for $K_{p}=3$ at the beginning of 6 July 2018. This section deals with the description of time variations of the Doppler shifts measured over different radio propagation paths. As a reference days, 6 July 2018 and 9 July 2018 are chosen. During all these days, multipath multiple-mode radio propagation occurs.

The seismic activity is the cause of observed aperiodic processes at ranges up to $(1-2) \times 10^{3} \mathrm{~km}$ from the epicenter, with an increase in the number of rays, and a marked broadening of the Doppler spectra (see Fig. 2). Wave disturbances that were generated by a surface by Raleigh wave propagated from the earthquake. The $1.7-$ $9 \%$ quasi-periodic variations were observed in the electron density. Oscillation train durations were found to be in the $26-58$-min range. A speed of propagation of $3 \mathrm{~km} / \mathrm{s}$ for these wave-like disturbances was equal to the speed of a Rayleigh wave. Wave-like disturbances showed 15-30-min periods. Such disturbances could be generated at the epicenter and propagated via atmospheric gravity waves that modify the ionospheric electron density. The $14-34 \%$ amplitude was observed in these electron density disturbances. Oscillation train durations were found to attain about 40-84 min, while the speed about $0.30-0.60 \mathrm{~km} / \mathrm{s}$. The most dramatic signature of the disturbances due to the earthquake is the spectrum broadening toward negative shifts with a 50-116-min delay which depends on the orientation of the radio path. Such a time delay suggests an approximately $0.3 \mathrm{~km} / \mathrm{s}$ speed, and the atmospheric gravity waves generated by the earthquake as the cause of this effect.

Table 1. Space weather state

\begin{tabular}{|c|c|c|c|c|c|c|c|c|c|}
\hline \multirow{2}{*}{ Date } & \multirow{2}{*}{$W$} & \multirow{2}{*}{$F_{10.7}$} & \multicolumn{2}{|c|}{$K p$} & \multicolumn{2}{|c|}{$D s t(\mathrm{nT})$} & \multicolumn{2}{c|}{$B_{z}(\mathrm{nT})$} & \multirow{2}{*}{$A p$} \\
\cline { 4 - 9 } & & & $\max$ & $\min$ & $\max$ & $\min$ & $\max$ & $\min$ & \\
\hline 4 July 2018 & 0 & 68 & $1+$ & $1-$ & 14 & 2 & 5.4 & -3.9 & 4 \\
\hline 5 July 2018 & 0 & 68 & $5-$ & $0+$ & 15 & -23 & 3.1 & -0.9 & 17 \\
\hline 6 July 2018 & 0 & 71 & $4-$ & $1-$ & 12 & -12 & 1.0 & -2.6 & 7 \\
\hline 7 July 2018 & 0 & 72 & 2 & $1-$ & 5 & -10 & 0.7 & -3.7 & 5 \\
\hline 8 July 2018 & 0 & 72 & $1+$ & $0+$ & 2 & -4 & 15.3 & -3.1 & 4 \\
\hline 9 July 2018 & 0 & 73 & $1-$ & 0 & 4 & -2 & 6.4 & -8.9 & 2 \\
\hline 10 July 2018 & 0 & 72 & $2+$ & $0+$ & 20 & 0 & 4.4 & -4.2 & 6 \\
\hline
\end{tabular}



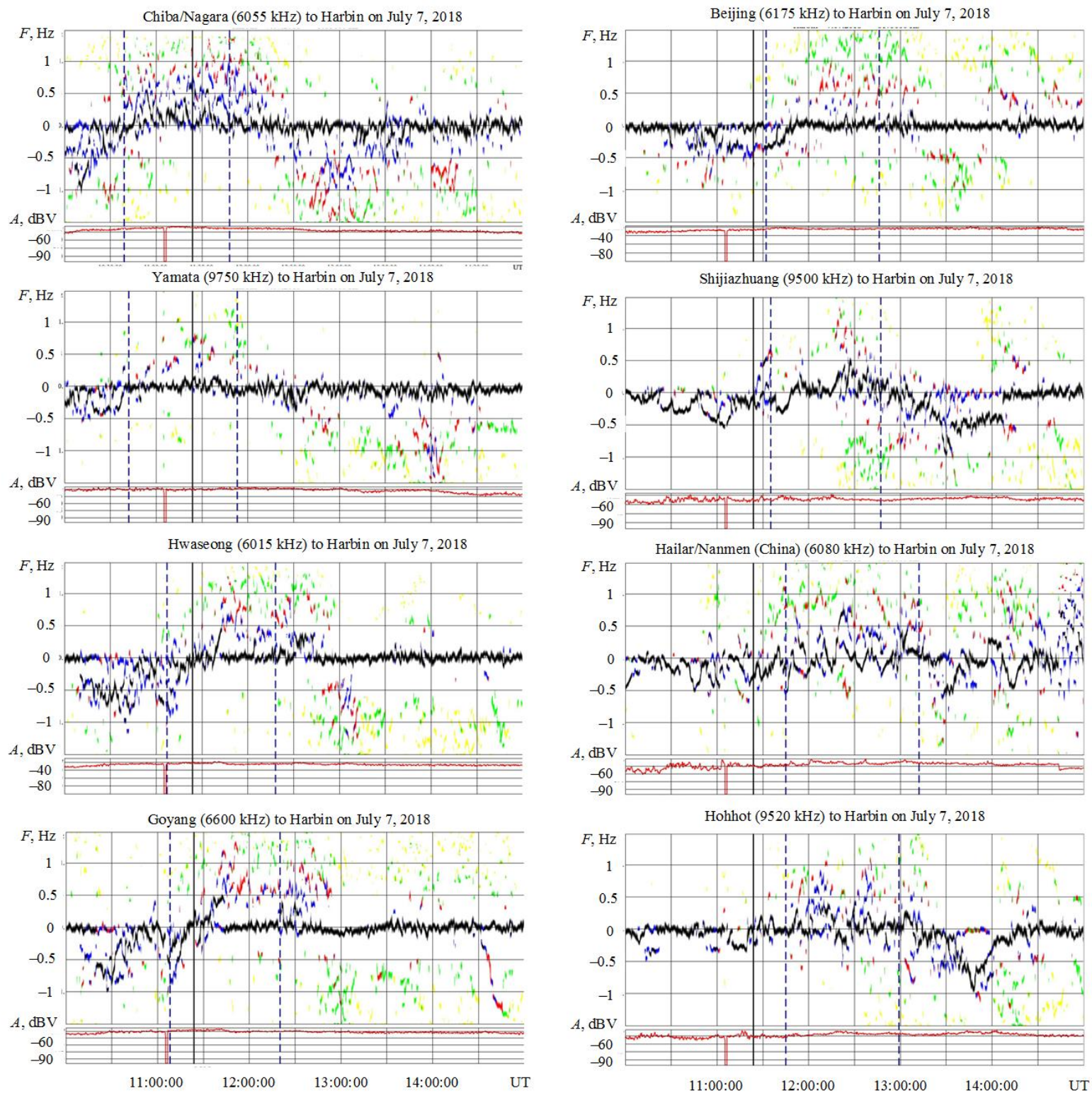

Fig. 2. Same as Fig. 1, but acquired during the submarine earthquake of Richter magnitude 5.9 that occurred of the coast of Japan at 11:23:50 UT on 7 July 2018 , with the epicenter coordinates $35.107^{\circ} \mathrm{N}, 140.42^{\circ} \mathrm{E}$ and with the hypocenter at a depth of $40 \mathrm{~km}$. The distance between the earthquake epicenter and the City of Harbin was equal to 1,650 km.

As can be seen in Fig. 2, the Doppler shift of the frequency was negative over the Hohhot to Harbin propagation path from 09:00 UT to 12:00 UT on July 7, 2018 (right-hand bottom panel), which means that the reflection level shifted upward, while the electron density in the ionosphere decreased. Over the 12:00 - 13:00 UT period, the Doppler shift of the frequency over all paths was becoming positive, and the reflection level shifted downwards. This was caused by an increase in the electron density. Quasi-periodic variations of the Doppler shift of the frequency were superimposed on its slow increases and decreases.

\section{Ionospheric Storm}

The magnetic storm of August 25-26, 2018 was the greatest in that year.

The state of the space weather over the interval August 23-29, 2018 was as follows. The peaks in the solarwind electron density, $N_{s w}$, occurred on August 24, 25, and 26, 2018. The largest enhancement, from 3-4 $\mathrm{cm}^{-3}$ to 15-20 $\mathrm{cm}^{-3}$, occurred during the night of August 25/26, 2018, when the solar-wind velocity varied from $300 \mathrm{~km}$ $\mathrm{s}^{-1}$ to $600 \mathrm{~km} \mathrm{~s}^{-1}$. On August 26, 2018, the solar-wind temperature increases from $5 \times 10^{4} \mathrm{~K}$ to $3 \times 10^{5} \mathrm{~K}$. During August 25-26, 2018, the solar wind dynamic pressure increases from $\sim 0.3 \mathrm{nPa}$ to $3 \mathrm{nPa}$, while the kinetic pressure of the solar wind remains almost an order of magnitude less, down to $0.6 \mathrm{nPa}$. The $B_{z}$ component of the interplanetary magnetic field attains maximum values of $-6 \mathrm{nT}$ and $-9 \mathrm{nT}$ on August 24 and 25, 2018, respectively. These large negative $B_{z}$ values indicate the onset of the magnetic storm at Earth. 
During the night of August 25/26, 2018, the parameter of Akasofu, a function showing the rate of the solar wind energy input into the Earth's magnetosphere, indicates an increase of anywhere from $\sim 1 \mathrm{GJ} \mathrm{s}^{-1}$ to $30 \mathrm{GJ} \mathrm{s}^{-1}$ and greater. The geospace storm emerges. The magnetic-activity index $A E$ grows from $\sim 100 \mathrm{nT}$ to $1,500 \mathrm{nT}$, the $K p$ index from $\sim 1$ to 7, but the Dst index first increases from 0 to $\sim 20 \mathrm{nT}$ and then, after 17:00 UT on August 25, 2018 , begin to decrease to approximately $-170 \mathrm{nT}$. The Dst index exhibits negative values over a few next days. The $K p$ index shows a new increase to a maximum of 6 on August 27, 2018. This means that the magnetic storm of alternating intensity extends from August 25 to August 28, 2018. The state of space weather is shown in Table 2. As can be seen from Table 2 , the solar activity was enhanced, and strong magnetic storm occurred $\left(K_{p \max }=\right.$ $\left.7+, A_{p \max }=67, D_{s t \min }=-174 \mathrm{nT}\right)$.

Analysis of the state of the ionosphere is based on the data acquired with the DPS-4 digisonde operating in the Republic of Korea $\left(37.14^{\circ} \mathrm{N}, 127.54^{\circ} \mathrm{E}\right)$, which provided universal time dependence of the $F_{2}$ layer critical frequency, $f_{o} F_{2}$. The $f_{o} F_{2}$ values observed from 22:00 UT on August 25, 2018 to 14:00 UT on August 26, 2018 exceed the $f_{o} F_{2}$ values observed over the respective time interval on the reference days of August 28/29, 2018 by a factor of 1.3-1.7 times. This indicates that a positive ionospheric storm occurred. Moreover, the storm was accompanied by repeated decreases of $1.5-2 \mathrm{MHz}$ in $f_{o} F_{2}$ values. This means that the ionospheric storm was multi-phase, positive excursions in $f_{o} F_{2}$ alternated with negative gaps in the $f_{o} F_{2}(t)$ dependence.

The ionospheric storm following a decrease in the Dst index at approximately 20:00 UT on August 25, 2018 was at first accompanied by an insignificant increase in the electron density, $N$. The next bursts in the electron density occurred at about 00:23 UT, 02:45 UT, 07:45 UT, 10:23 UT, and 12:45 UT on August 26, 2018. These bursts in the electron density alternated with density decreases by a factor of $1.8-2.3$ times. Hence, this storm most distinctive feature is its multi-phase nature, two positive storms alternated with three negative storms. It should be remarked that the nature of positive and negative storms has been discussed in several papers $[34-38]$.

The ionospheric storm led to an increase in the number of rays, Doppler spectrum broadening, and significant Doppler shifts over the ray paths. The magnitude of alternating-sign aperiodic variations in the Doppler shift of the frequency and the amplitude of their oscillations have been shown not to exceed $0.6-$ $0.7 \mathrm{~Hz}$ and $0.5-0.6 \mathrm{~Hz}$, respectively (see Fig. 3). The magnetic storm has been established to be accompanied by multi-phase ionospheric storm lasted over 16 hours, from 22:00 UT on August 25, 2018 to 14:00 UT on August 26, 2018. The distinctive feature of this ionospheric storm is that two positive storms alternated with three negative storms. Through the course of the storm, increases in the reflection level of each radio path by $\sim 50-100 \mathrm{~km}$ and reflection height oscillations with amplitude of $\sim 30-40 \mathrm{~km}$ were repeatedly observed. Rises in the levels of reflection were followed by lowerings of the reflection heights by many tens of kilometers. A rise and a lowering of the levels of reflection were caused by a decrease by a factor of $1.5-2$ and an increase by a few times in the electron density.

The maximum increase in the $E$-region electron density attained 1.5 times and in the $F$ region 3 times. The relative amplitude of oscillations in the electron density attained many tens of percent. On the reference days, the amplitude of oscillations in the Doppler shift of the frequency was a few times less. The oscillations observed in the Doppler shift of the frequency were apparently due to the generation of the atmospheric gravity waves in high latitudes and by their subsequent propagation from high to middle latitudes where the observational facilities are located. The speed of the wave disturbances was equal to approximately $275-480 \mathrm{~m} \mathrm{~s}^{-1}$ and the period to $\sim 60 \mathrm{~min}$.

The synchronicity in the variations for all paths provide evidence for the ionospheric disturbance to be large-scale, if not a global-scale one. The scale of the disturbance was no less than $(1-2) \times 10^{3} \mathrm{~km}$. On the reference days, similar variations in the parameters of the Doppler spectra were absent. Hence, the variations observed in the Doppler shift of the frequency were caused by the ionospheric storm.

It should be remarked that another magnetic storm with $K p_{\max }$ of $\sim 5$ and $D s t_{\min }$ of $\sim-50 \mathrm{nT}$ occurred on August 27, 2018, when the ionospheric disturbances were considerably smaller than on August 26, 2018.

Table 2. Space Weather State

\begin{tabular}{|c|c|c|c|c|c|c|c|c|c|}
\hline \multirow{2}{*}{ Date } & \multirow{2}{*}{$W$} & \multirow{2}{*}{ F 10.7} & \multicolumn{2}{|c|}{$K p$} & \multicolumn{2}{|c|}{ Dst (nT) } & \multicolumn{2}{|c|}{$B_{z}(\mathrm{nT})$} & \multirow[t]{2}{*}{$A p$} \\
\hline & & & $\max$ & $\min$ & $\max$ & $\min$ & $\max$ & $\min$ & \\
\hline 23 August 2018 & 15 & 70 & $2-$ & $0+$ & -4 & -15 & 1.4 & -3.4 & 4 \\
\hline 24 August 2018 г. & 29 & 72 & $3-$ & 0 & 8 & -11 & 0.6 & -1.8 & 4 \\
\hline 25 August 2018 г. & 31 & 72 & $4+$ & $1-$ & 19 & -49 & 1.2 & -3.0 & 12 \\
\hline 26 August 2018 г. & 26 & 71 & $7+$ & 3 & -60 & -174 & 3.5 & -4.7 & 67 \\
\hline 27 August 2018 г. & 12 & 70 & $6-$ & $1+$ & -48 & -70 & 4.8 & -5.3 & 25 \\
\hline 28 August 2018 г. & 11 & 70 & $4-$ & $0+$ & -27 & -47 & 2.7 & -1.5 & 8 \\
\hline 29 August 2018 г. & 0 & 71 & $2+$ & $1-$ & -31 & -40 & 4.2 & -1.8 & 5 \\
\hline
\end{tabular}



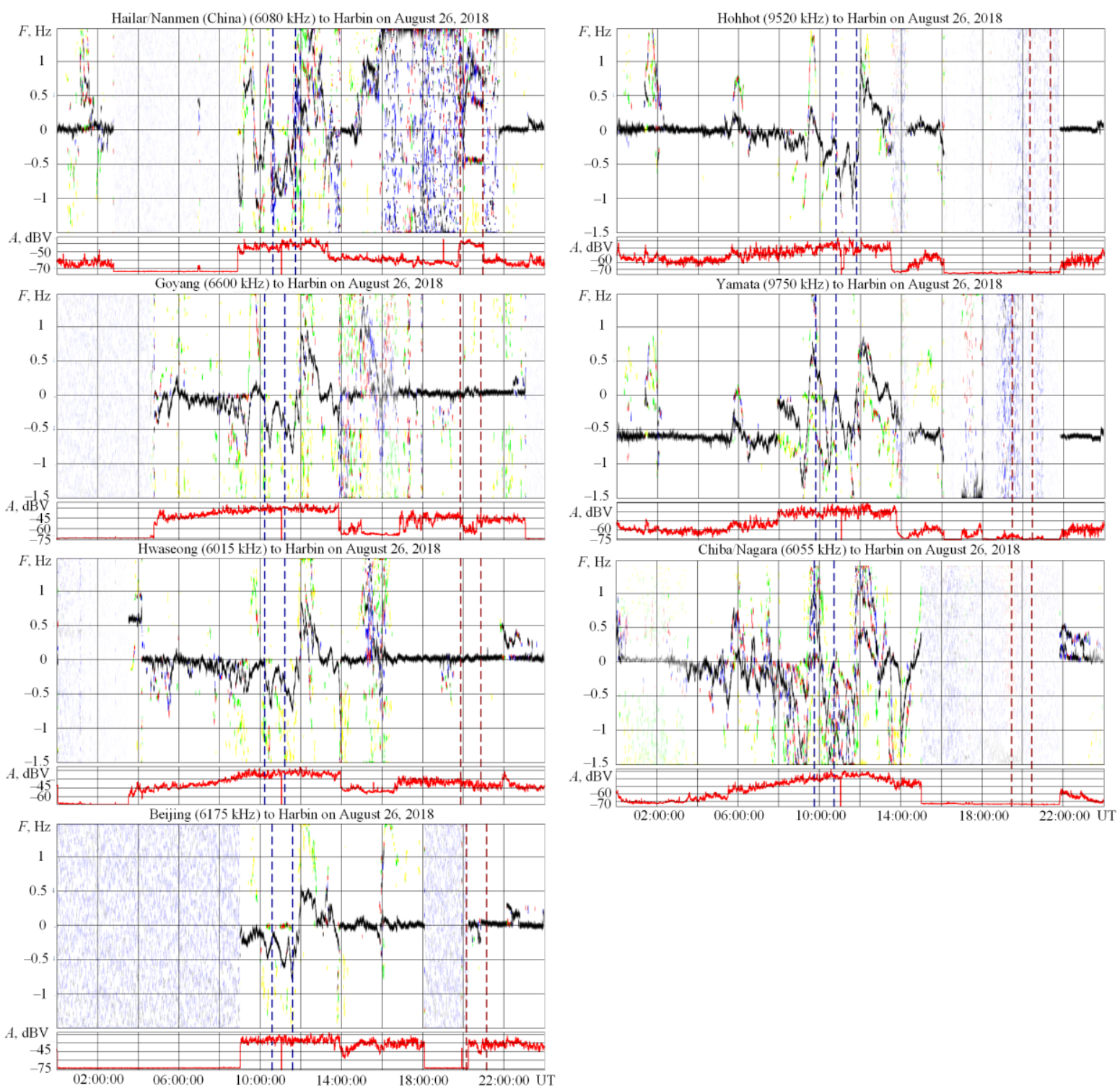

Fig. 3. Same as Fig. 1, but for the Hailar to Harbin, Goyang to Harbin, Hwaseong to Harbin, Beijing to Harbin, Hohhot to Harbin, Yamata to Harbin, Chiba to Harbin radio propagation paths (panels from top to bottom and left to right) on 26 August 2018.

\section{Solar Eclipse}

The solar eclipse under study, Saros 155 [https://eclipse.gsfc.nasa.gov/SEsaros/SEsaros.html], was observed in Asia, North Europe, Greenland, and in the North of the North America on 11 August 2018. The eclipse showed maximum magnitude, $M$, of 0.7368 at $\left(70.4^{\circ} \mathrm{N}, 174.5^{\circ} \mathrm{E}\right)$ in the East Siberia Sea. Within the People's Republic of China and its vicinity, the eclipse showed lesser magnitudes, 0.073 to 0.516 . The magnitudes referred to below correspond to the magnitudes at the radio propagations path midpoints. The corresponding obscurations, $A_{m}$, varied from 0.024 to 0.415 . One of the event features is that the eclipse was observed before and during the sunset interval.

The analysis of the space weather state could be used to distinguish between the solar eclipse effects and the effects due to the dusk terminator. The state of space weather, prior to the solar eclipse, during, and after it, is shown in Table 3. As can be seen from Table 3, the solar activity was low, and the magnetic disturbances were insignificant. The conditions were conducive to observing effects of the solar eclipse. Consequently, they could not significantly affect the estimation of the eclipse effects. Thus, the detection of the effects caused by the solar eclipse with the effects from the dusk terminator in the background should be easier.

As can be seen in Fig. 4 , the eclipse is associated at first with a negative and then with a positive Doppler shift of smaller magnitude, the generation of oscillations in the range of atmospheric gravity wave periods, and an increase in a ray number.

The results obtained in this work expand the results presented in the monograph [39]. 
Table 3. Space Weather State

\begin{tabular}{|c|c|c|c|c|c|c|c|c|c|}
\hline \multirow{2}{*}{ Date } & \multirow{2}{*}{$W$} & \multirow{2}{*}{$F_{10.7}$} & \multicolumn{2}{|c|}{$K p$} & \multicolumn{2}{c|}{ Dst $(\mathrm{nT})$} & \multicolumn{2}{c|}{$B_{z}(\mathrm{nT})$} & $A p$ \\
\cline { 4 - 9 } & & & $\max$ & $\min$ & $\max$ & $\min$ & $\max$ & $\min$ & \\
\hline 8 August 2018 & 0 & 70 & $2-$ & $1-$ & 10 & -6 & 2.8 & -2.6 & 4 \\
\hline 9 August 2018 & 0 & 70 & $1+$ & $0+$ & 5 & -10 & 3.6 & -2.9 & 4 \\
\hline 10 August 2018 & 0 & 70 & $1+$ & $0+$ & 9 & -1 & 1.0 & -1.8 & 3 \\
\hline 11 August 2018 & 0 & 67 & $4-$ & $1+$ & 9 & -16 & 2.9 & -3.1 & 10 \\
\hline 12 August 2018 & 0 & 68 & 2 & $1-$ & 10 & -9 & 3.6 & -2.1 & 5 \\
\hline 13 August 2018 & 0 & 68 & $1+$ & $0+$ & 0 & -14 & 1.4 & -3.0 & 4 \\
\hline 14 August 2018 & 12 & 69 & $1+$ & $0+$ & 16 & -2 & 1.3 & -1.7 & 3 \\
\hline
\end{tabular}

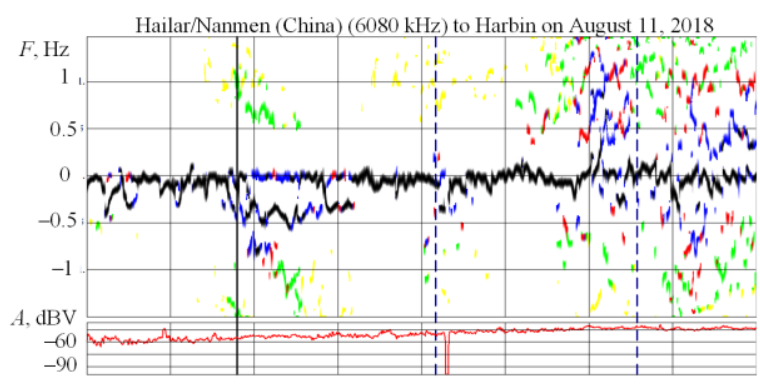

Govang (6600 kHz) to Harbin on August 11, 2018

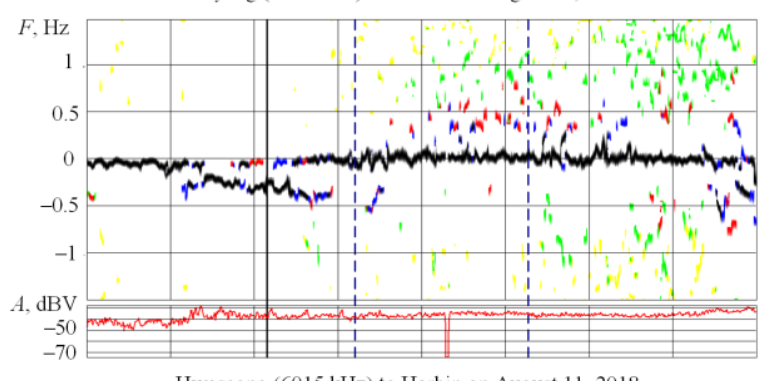

Hwaseong (6015 kHz) to Harbin on August 11, 2018

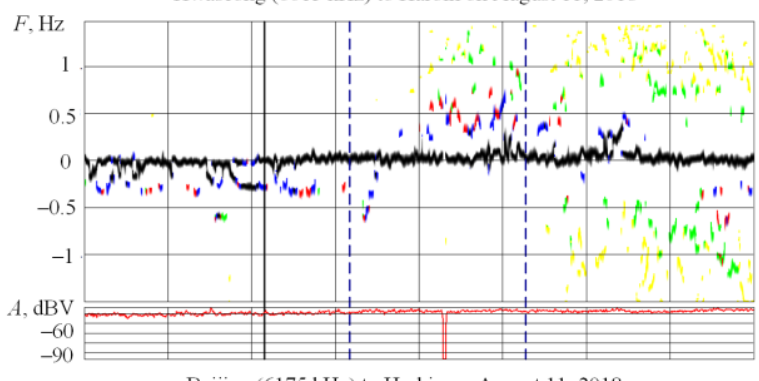

Beijing (6175 kHz) to Harbin on August 11, 2018

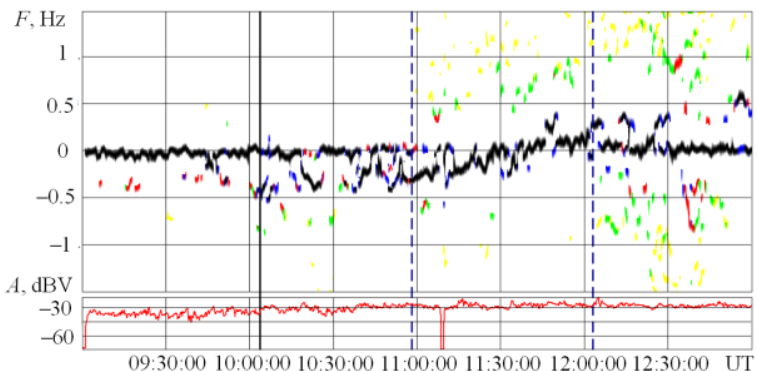

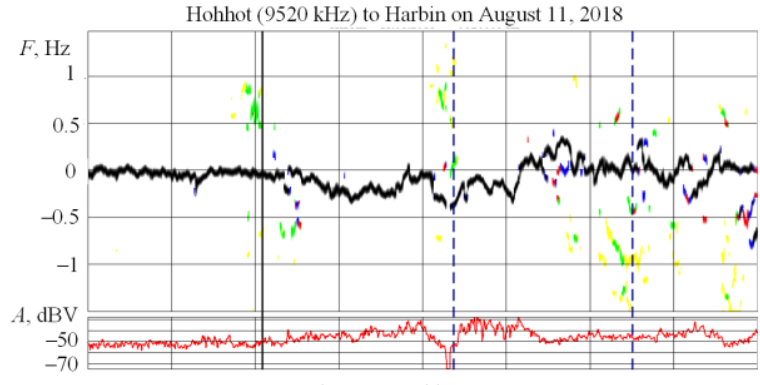

Yamata (9750 kHz) to Harbin on August 11, 2018

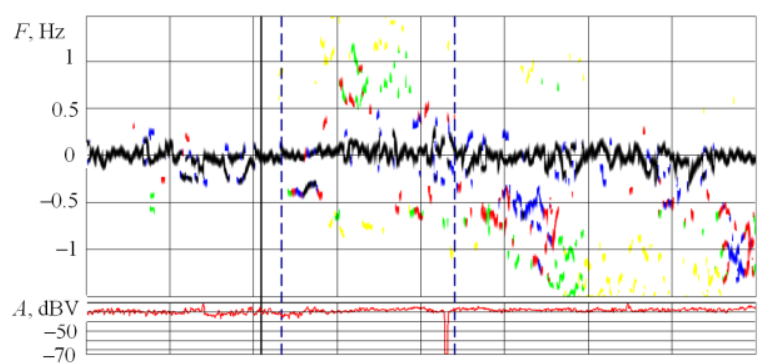

Chiba/Nagara (6055 kHz) to Harbin on August 11, 2018

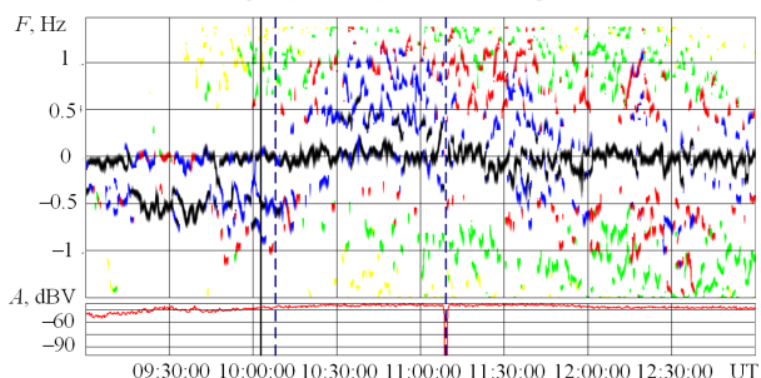

09:30:00 10:00:00 10:30:00 11:00:00 11:30:00 12:00:00 12:30:00 UT

Fig. 4. Same as Fig. 1, but during the solar eclipse of August 11, 2018.

\section{SUMMARY AND CONCLUSIONS}

1. The multi-frequency coherent passive radar that has been developed at the Harbin Engineering University, People's Republic of China (PRC) for sounding the ionosphere remotely over different radio paths has shown a high efficiency of observing dynamic processes occurring in the ionosphere. 
The passive radar at the City of Harbin is situated near the $120^{\circ} \mathrm{E}$ meridian. At this meridian, the facilities included in the Meridian Space Weather Monitoring Project are situated [40]. The joint use of radio instrumentation in the Meridian Project and the passive radar at the Harbin Engineering University in collaborative studies will permit an accurate specification of the near-Earth environment under conditions of magnetospheric/ionospheric disturbance.

2. The radar proved to be capable of probing the dynamics of the ionosphere modified by the dusk terminator. The sensitivity of the Doppler variations to dynamic processes occurring in the ionosphere is greater than the sensitivity of amplitude variations. The sunset terminator has caused Doppler spectrum widening, the generation of the atmospheric gravity waves, and an increase in the number of rays reflected from the ionosphere.

3. The radar proved to be capable of probing the dynamics of the ionosphere modified by the earthquake having a moderate Richter magnitude of 5.9 in the $\sim(1-2) \times 10^{3}-\mathrm{km}$ range from the epicenter. The seismic activity is the cause of observed aperiodic processes that occurred in Japan on July 7, 2018 at ranges up to (1 2) $\times 10^{3} \mathrm{~km}$ from the epicenter, with an increase in the number of rays, and a marked broadening of the Doppler spectra. Wave disturbances that were generated by a surface by Raleigh wave propagated from the earthquake. The 1.7-9\% quasi-periodic variations were observed in the electron density. Oscillation train durations were found to be in the $26-58$-min range. A speed of propagation of $3 \mathrm{~km} / \mathrm{s}$ for these wave-like disturbances was equal to the speed of a Rayleigh wave. Wave-like disturbances showed 15 - 30-min periods. Such disturbances could be generated at the epicenter and propagated via atmospheric gravity waves that modify the ionospheric electron density. The $14-34 \%$ amplitude was observed in these electron density disturbances. Oscillation train durations were found to attain about $40-84 \mathrm{~min}$, while the speed about $0.30-0.60 \mathrm{~km} / \mathrm{s}$. The most dramatic signature of the disturbances due to the earthquake is the spectrum broadening toward negative shifts with a 50116-min delay which depends on the orientation of the radio path. Such a time delay suggests an approximately $0.3 \mathrm{~km} / \mathrm{s}$ speed, and the atmospheric gravity waves generated by the earthquake as the cause of this effect.

4. Using the coherent multi-path radio facility for oblique-incidence probing the ionosphere, observations have been made of radio wave characteristics in the $\sim 6-10 \mathrm{MHz}$ band and of disturbances in the ionosphere over the People's Republic of China during the strong geomagnetic storm $(K p=7+)$ on August 25 - 26, 2018. Aperiodic and quasi-periodic variations in the Doppler shift of the frequency have been detected. The ionospheric storm led to an increase in the number of rays, Doppler spectrum broadening, and significant Doppler shifts over the ray paths. The magnitude of alternating-sign aperiodic variations in the Doppler shift of the frequency and the amplitude of their oscillations have been shown not to exceed $0.6-0.7 \mathrm{~Hz}$ and $0.5-$ $0.6 \mathrm{~Hz}$, respectively. The magnetic storm has been established to be accompanied by multi-phase ionospheric storm lasted over 16 hours, from 22:00 UT on August 25, 2018 to 14:00 UT on August 26, 2018. The distinctive feature of this ionospheric storm is that two positive storms alternated with three negative storms. Through the course of the storm, increases in the reflection level of each radio path by $\sim 50-100 \mathrm{~km}$ and reflection height oscillations with amplitude of $\sim 30-40 \mathrm{~km}$ were repeatedly observed. Rises in the levels of reflection were followed by lowerings of the reflection heights by many tens of kilometers. A rise and a lowering of the levels of reflection were caused by a decrease by a factor of $1.5-2$ and an increase by a few times in the electron density.

The maximum increase in the $E$-region electron density attained 1.5 times and in the $F$ region 3 times. The relative amplitude of oscillations in the electron density attained many tens of percent. On the reference days, the amplitude of oscillations in the Doppler shift of the frequency was a few times less. The oscillations observed in the Doppler shift of the frequency were apparently due to the generation of the atmospheric gravity waves in high latitudes and by their subsequent propagation from high to middle latitudes where the observational facilities are located. The speed of the wave disturbances was equal to approximately $275-480 \mathrm{~m} \mathrm{~s}^{-1}$ and the period to $\sim 60 \mathrm{~min}$.

5. The solar eclipse of August 11, 2018is associated at first with a negative and then with a positive Doppler shift of smaller magnitude, the generation of oscillations in the range of atmospheric gravity wave periods, and an increase in a ray number.

Acknowledgements. Work by Qiang Guo and Yu Zheng was supported by Central University Basic Research Business Expenses Special Fund Project (grant numbers HEUCFG201832 and HEUCFP201840), China; Heilongjiang Province Applied Technology Research and Development Program National Project Provincial Fund (grant number GX16A007), China; and Open Fund for National Key Laboratory of Deep-Sea Manned Equipment (grant number702SKL2017200, China.Work by L. F.Chernogor was supported by Ministry of Education and Science of Ukraine research project \#0116U000822. Work by K. P. Garmash was supported by Ministry of Education and Science of Ukraine research project \#0115U000463. Work by V. T. Rozumenko was supported by Ministry of Education and Science of Ukraine research project \#0116U000833. 


\section{CONFLICTS OF INTEREST}

The Authors do not have conflicts of interest.

\section{Authors' ORCID ID}

Q. Guo (iD https://orcid.org/0000-0002-8366-7163

Yu Zheng (iD https://orcid.org/0000-0001-6166-5733

L. F. Chernogor (iD https://orcid.org/0000-0001-5777-2392

K. P. Garmash (iD https://orcid.org/0000-0002-0844-5456

V. T. Rozumenko (iD https://orcid.org/0000-0002-2941-8887

\section{REFERENCES}

1. Galushko, V. G., Beley, V. S., Koloskov, A. V., Yampolski, Y. M., Paznukhov, V. V., Reinisch, B. W., Foster, J. C., Erickson, P. J., "Frequency-and-angular HF sounding and ISR diagnostics of TIDs," Radio Science, Vol. 38, No. 6, pp. 10-1-10-9, 2003. doi: 10.1029/2002RS002861.

2. Reinisch, B. W., Galkin, I. A., Khmyrov, G. M., Kozlov, A. V., Bibl, K., Lisysyan, I. A., Cheney, G. P., Huang, X., Kitrosser, D. F., Paznukhov, V. V., Luo, Y., Jones, W., Stelmash, S., Hamel, R., Grochmal, J., "New Digisonde for research and monitoring applications," Radio Science, Vol. 44, No. 1, pp. 1-15, 2009. doi: 10.1029/2008RS004115.

3. Reinisch, B. W., Galkin, I. A., "Global Ionospheric Radio Observatory (GIRO)," Earth, Planets and Space, Vol. 63, No. 4. pp. $377-381,2011$.

4. Verhulst, T., Altadill, D., Mielich, J., Reinisch, B., Galkin, I., Mouzakis, A., Belehaki, A., Burešová, D., Stankov, S., Blanch, E., Kouba, D., "Vertical and oblique HF sounding with a network of synchronised ionosondes," Advances in Space Research, Vol. 60, No. 8, pp. 1644 - 1656, 2017.

5. Ivanov, V. A., Kurkin, V. I., Nosov, V. E., Uryadov, V. P., Shumaev, V. V., "Chirp Ionosonde and its Application in the Ionospheric Research," Radiophysics and Quantum Electronics, Vol. 46, No. 11, pp. 821 - 851, 2003. doi:10.1023/b:raqe.0000028576.51983.9c.

6. Zalizovski, V., Kascheyev, A. S., Kascheev, S. B., Koloskov, A. V., Lisachenko, V. N., Paznukhov, V. V., Pikulik, I. I., Sopin, A. A., Yampolski, Y. M., "Prototype of a portable coherent ionosonde," Space Science and Technology, Vol. 24, No. 3 (112), pp. 10-22, 2018 (in Russian). doi: 10.15407/knit2018.03.010.

7. Galushko, V. G., Kascheev, A. S., Paznukhov, V. V., Yampolski, Y. M., Reinisch, B. W., "Frequencyand-angular sounding of traveling ionospheric disturbances in the model of three-dimensional electron density waves," Radio Science, Vol. 43, No. 4, pp. 1-10, 2008. doi: 10.1029/2007RS003735.

8. Pietrella, M., Perrone, L., Fontana, G., Romano, V., Malagnini, A., Tutone, G, Zolesi, B., Cander, Y. R., Belehaki, A., Tsagouri, I., Kouris, S. S., Vallianatos, F., Makris, J., Angling, M., "Obliqueincidence ionospheric soundings over Central Europe and their application for testing now casting and long term prediction models," Advances in Space Research, Vol. 43, No. 11, pp. 1611 - 1620, 2009.

9. Mlynarczyk, J., Koperski, P., Kulak, A., "Multiple-site investigation of the properties of an HF radio channel and the ionosphere using Digital Radio Mondiale broadcasting," Advances in Space Research. Vol. 49, No. 1, pp. 83 - 88, 2012.

10. Paznukhov, V. V., Galushko, V. G., Reinisch, B. W., "Digisonde observation of TIDs with frequency and angular sounding technique," Advances in Space Research, Vol. 49, No. 4, pp. 700 - 710, 2012. doi:10.1016/j.asr.2011.11.012.

11. Vertogradov, G. G., Uryadov, V. P., Vertogradova, E. G., Vertogradov, V. G., Kubatko, S. V., "Chirp ionosonde-radiodirection finder as a new tool for studying the ionosphere and radio-wave propagation," Radiophysics and Quantum Electronics, Vol. 56, No. 5, pp. 259 - 275, 2013. doi: 10.1007/S11141-0139431-3.

12. Shi, S. Z., Chen, G., Yang, G. B., Li, T., Zhao, Z. Y., Liu, J. N., "Wuhan ionospheric oblique-incidence sounding system and its new application in localization of ionospheric irregularities," IEEE Transactions on Geoscience and Remote Sensing, Vol. 53, No. 4, pp. 2185 - 2194, 2015.

13. Shi, S. Z., Yang, G. B., Zhao, Z. Y., Liu, J. N., "A novel ionospheric oblique-incidence sounding network consisting of the ionospheric oblique backscatter sounder and parasitic oblique-incidence sounder," IEEE Trans. Geoscience and Remote Sensing Letters, Vol. 12, No. 10, pp. 2070 - 2074, 2015.

14. Heitmann, J., Cervera, M. A., Gardiner-Garden, R. S., Holdsworth, D. A., MacKinnon, A. D., Reid, I. M., Ward, B. D., "Observations and modeling of ionospheric disturbance signatures from an Australian network of oblique angle of arrival sounders," 32nd URSI GASS, Montreal, 19 - 26 August 2017, pp. 1-4.

15. Laštovička, J., Chum, J., "A review of results of the international ionospheric Doppler sounder network," Advances in Space Research, Vol. 60, No. 8, pp. 1629 - 1643, 2017. 
16. Garmash, K. P., Rozumenko, V. T., Tyrnov, O. F., Tsymbal, A. M., Chernogor, L. F., "Radio Studies of processes in the near-Earth plasma disturbed by high-energy sources. Part 1," Telecommunications and Radio Engineering, No. 7. pp. 3 - 15, 1999.

17. Blagoveshchenskaya, N. F., "Geophysical effects of active experiments in the near-Earth space," SaintPetersberg: Gidrometeoizdat, 2001, 287 p. (in Russian).

18. Chernogor, L. F., Garmash, K. P., Podnos, V. A., Tyrnov, O. F., "V. N. Karazin Kharkiv National University radio physics observatory as a facility for monitoring the ionosphere during space experiments," In "Ionosat-Micro" Space Project". Kyiv: Academperiodika, 2013, pp. 160 - 182. (in Russian).

19. Garmash, K. P., Gokov, A. M., Kostrov, L. S., Rozumenko, V. T., Tyrnov, O. F., Fedorenko, Y. P., Tsymbal, A. M., Chernogor, L. F., "Radiophysical Investigations and Modeling of Ionospheric Processes Generated by Sources of Various Nature. 1. Processes in a Naturally Disturbed Ionosphere. Technical Facilities," Telecommunications and Radio Engineering, Vol. 53, No. 4 - 5, pp. 6-20, 1999.

20. Garmash, K. P., Gokov, A. M., Kostrov, L. S., Rozumenko, V. T., Tyrnov, O. F., Fedorenko, Y. P., Tsymbal, A. M., Chernogor, L. F., "Radiophysical Investigations and Modeling of Ionospheric Processes Generated by Sources of Various Nature. 2. Processes in a Modified Ionosphere. Signal Parameter Variations. Disturbance Simulation,” Telecommunications and Radio Engineering, Vol. 53, No. 6, pp. 1-22, 1999.

21. Blagoveshchenskaya, N. F., Andreev, A. D., Kornienko, V. A. , "Ionospheric wave processes during HF heating experiments," Advances in Space Research, Vol. 15, No. 12, pp. 45-48, 1995.

22. Chernogor, L. F., Garmash, K. P., Podnos, V. A., Rozumenko, V. T., Tsymbal, A. M., Tyrnov, O. F. , "The Upgraded Kharkiv V. N. Karazin National University Radiophysical Observatory," Sun and Geosphere, Vol. 7, No. 2, pp. 133 - 139, 2012.

23. Huang, D., Liu, E., Hu, H., Liu, J., "Algorithm for the estimation of ionosphere parameters from ground scatter echoes of SuperDARN, Sci. China Technol. Sci. Vol. 61, No. 11, pp. 1755-1764, 2018.

24. Guo, Q., Chernogor, L. F., Garmash K. P., Rozumenko V. T., Zheng Y. Dynamical processes in the ionosphere following the moderate earthquake in Japan on 7 July 2018 // Journal of Atmospheric and Solar-Terrestrial Physics, Vol. 186, pp. 88 - 103, 2019.

25. Guo, Q., Zheng, Y., Chernogor, L. F., Garmash, K. P., Rozumenko, V. T., Passive HF Doppler Radar for Oblique-Incidence Ionospheric Sounding // 2019 IEEE 2nd Ukraine Conference on Electrical and Computer Engineering. Lviv, Ukraine, July 2-6, 2019, pp. 88 - 93.

26. Chernogor, L. F., Physics of geocosmic storms (in Russian) / L. F. Chernogor, I. F. Domnin // V. N. Karazin Kharkiv National University Publ., Kharkiv, 2014. - 408 p.

27. Dynamical processes in the ionosphere following the moderate earthquake in Japan on 7 July 2018 / Guo, Q., Chernogor, L. F., Garmash, K. P., et al. // Journal of Atmospheric and Solar-Terrestrial Physics, Vol. 186, pp. 88 - 103, 2019.

28. Physical Processes Operating in the Ionosphere after the Earthquake of Richter Magnitude 5.9 in Japan on July 7, 2018 / Chernogor, L. F., Garmash, K. P., Guo, Q., et al. // Astronomy and Space Physics in the Kyiv University. Book of Abstracts. International Conference. May 28 - 31, 2019, pp. $87-88$.

29. Effects of the Severe Ionospheric Storm of 26 August 2018. Chernogor, L. F., Garmash, K. P., Guo, Q., et al. // Astronomy and Space Physics in the Kyiv University. Book of Abstracts. International Conference. Kyiv, Ukraine, May 28 - 31, 2019, pp. 88 - 90.

30. Passive HF Doppler Radar for Oblique-Incidence Ionospheric Sounding / Guo, Q., Zheng, Y., Chernogor, L. F., et al. // 2019 IEEE 2nd Ukraine Conference on Electrical and Computer Engineering. Lviv, Ukraine, July 2-6, 2019, pp. $88-93$.

31. The Parameters of the Infrasonic Waves Generated by the Chelyabinsk meteoroid: System Statistic Analysis Results / Guo, Q., Zheng, Y., Chernogor, L. F., et al. // 2019 IEEE 2nd Ukraine Conference on Electrical and Computer Engineering. Lviv, Ukraine, July 2-6, 2019, pp. 938 - 941.

32. Physical Effects of the Severe Ionospheric Storm of 26 August 2018 / Chernogor, L. F., Garmash, K. P., Guo, Q., et al. // Fifth UK-Ukraine-Spain Meeting on Solar Physics and Space Science. Program, Abstracts, Information. Kyiv, Ukraine, August 26 - 30, 2019, pp. 33.

33. Marple, S. L., Jr., "Digital spectral analysis: with applications," Englewood Cliffs, N.J.: Prentice-Hall, Inc., 1987.

34. PRIME (COST 238) Studies of Ionospheric Storm Effects / Bradley, P. A., Cander, L. R., Kutiev, I., Hanbaba R. // Adv. Space Res., Vol. 20, No. 9, pp. 1669-1678, 1997.

35. Danilov, A. D., Effects of geomagnetic storms on the ionosphere and atmosphere / Danilov, A. D., Lastovička, J. // Inter. J. Geomagn. Aeron., Vol. 2, No. 3. - pp. 209-224, 2001.

36. Danilov, A. D., Ionospheric storms in the F2 region. Morphology and physics (review) (in Russian) / Danilov, A. D., Morozova, L. D. // Geomagnetism and Aeronomy, Vol. 25, No. 5, pp. 705 - 721, 1985.

37. Prölss, G. W., Ionospheric F-region storms / Prölss, G. W. // Handbook of Atmospheric Electrodynamics; Edited by H. Volland. CRC Press, Roca Raton, Fla., Vol. 2, pp. 195-248, 1995. 
38. Buonsanto, M. J., Ionospheric Storms-a Review / Buonsanto, M. J. // Space Sci. Rev., Vol. 88, pp. 563601, 1999.

39. Chernogor, L. F. Physical effects of solar eclipses in atmosphere and geospace: Monograph / L. F. Chernogor, Kharkiv National University, 487 p., 2013.

40. Ji, W., Chi, W., Fan, Q., "Introduction to meridian space weather monitoring project," J. Space Sci., Vol. 26, pp. $17-24,2006$. 